Volume 4 No. 3 Juli 2019

p-ISSN: 2477-8192 dan e-ISSN: 2502-2776

\title{
KESESUAIAN PENGGUNAAN LAHAN PERMUKIMAN DI KECAMATAN KATOBU DAN KECAMATAN DURUKA KABUPATEN MUNA BERBASIS SIG
}

\author{
Deris $^{1}$, Ramli $^{2}$ \\ ${ }^{1}$ Program Studi Pendidikan Geografi \\ Universitas Halu Oleo \\ Email: deriskendari123@gmail.com \\ ${ }^{2}$ Program Studi Pendidikan Geografi \\ Universitas Halu Oleo \\ Email: deriskendari123@gmail.com
}

(Received: 4 Mei 2019 ; Reviewed: 11 Mei 2019; Accepted: 8 Juli; Published: 9 Juli 2019)

(C)2019 - Jurnal Penelitian Pendidikan Geografi. Ini adalah artikel dengan

\begin{abstract}
The Population growth in Katobu subdistrict and Duruka Subdistrict are quite rapid, making more land use for settlements. Howefer, not all land is suitable for settlements, to anticipate settlements on land unsuitable, clear information is needed regarding the suitability of land for settlements. The purpose if this study are (1) to know the description of settlement land suitability in Katobu and Duruka Subdistricts, and (2) to know the suitability of residential land use in Katobu and Duruka Subdistricts. The research method used is descriptive qualitative method with spatial analysis out by scoring, overlaying, and buffer parameters of settlement land suitability by using Geographic Information Systems. The result showed that katobu sub-district had land suitable for settlement covering 551,41 ha, conditionally suitable land area covering 50,97 ha, and land that not suitable covering 871,1 ha. Duruka subdistrict has land suitable for settlements covering 869,1 ha, conditionally suitable land area of 67,81 ha, and land that not suitable covering 243,48 ha. The analysis of suitability settlement land use showed that Katobu subdistrict has use of settlement land on land suitable to an area of 421,86 ha, in conditionally appropriate land is 8,37 ha, on not suitable land covering 46,73 ha. Duruka subdistrict has use of settlement land on land according to an area of 172,93 ha, on conditionally appropriate land covering an area of 0,63 ha and on not suitable land area of 12,26 ha.
\end{abstract}

Keywords: Mapping, GIS, Suitability of Settlemen Land, Suitability of Land Use.

\section{ABSTRAK}

Pertumbuhan penduduk di Kecamatan Katobu dan Kecamatan Duruka yang begitu pesat membuat semakin banyaknya penggunaan lahan untuk permukiman. Namun tidak semua lahan cocok untuk permukiman, untuk mengantisipasi adanya permukiman dilahan lahan tidak sesuai maka dibutuhkan informasi yang jelas terkait kesesusian lahan permukiman. Tujuan penelitian ini adalah (1) untuk mengetahui gambaran kesesuaian lahan permukiman di Kecamatan Katobu dan Kecamatan Duruka, dan (2) untuk mengetahui kesesuaian penggunaan lahan permukiman di Kecamatan Katobu dan Kecamatan Duruka. Metode penelitian yang digunakan adalah metode deskriptif kualitatif dengan analisis spasial dengan 
cara scoring, overlay, dan buffer parameter kesesuaian lahan permukiman menggunakan sistem sistem informasi geografis. Hasil penelitian menunjukkan Kecamatan Katobu memiliki lahan sesuai untuk permukiman seluas 551,41ha, lahan sesuai bersyarat seluas 50,97 ha, dan lahan tidak sesuai seluas 871,1 ha. Kecamatan Duruka memiliki lahan sesuai untuk permukiman seluas 869,1 ha, lahan sesuai bersyarat seluas 67,81 ha, dan lahan tidak sesuai seluas 243,48 ha. Analisis kesesuaian penggunaan lahan permukiman menunjukkan bahwa Kecamatan Katobu memiliki penggunaan lahan permukiman di lahan sesuai seluas 421,86 ha, di lahan sesuai bersyarat seluas 8,37 ha, dan dilahan tidak sesuai 46,73 ha. Kecamatan Duruka memiliki penggunaan lahan permukiman pada lahan sesuai 172,93 ha, pada lahan sesuai bersyarat seluas 0,63 ha dan pada lahan tidak sesuai seluas 12,26.

Kata Kunci: Pemetaan, SIG, Kesesuaian Lahan Permukiman, Kesesuaian Penggunaan Lahan.

\section{PENDAHULUAN}

Perkembangan teknologi informasi yang semakin pesat membuat pemanfaatannya semakin berkembang pada berbagai bidang, termasuk pembangunan. Banyak penemuanpenemuan baru terkait penggunaan dan pemanfaatan teknologi, salah satunya adalah sistem informasi geografis (Geographic Informasi Sytem). Menurut Prahasta (2009) dan Lestari, dkk. (2016), SIG merupakan gabungan dari tiga unsur pokok: sistem, informasi, dan geografis. Salah satu manfaat SIG adalah memberikan informasi dan kemudahan kepada para pengguna khususnya yang berkaitan dengan aspek keruangan. Dengan adanya teknologi ini akan memudahkan dalam hal pemetaan termasuk dalam hal analisis keruangan untuk pembangunan.

Informasi keruangan yang diperoleh dari hasil pemetaan biasanya digunakan oleh para pengambil keputusan untuk menentukan kebijakan yang akan diambil khususnya yang berkaitan dengan pembangunan. Pembangunan yang dilakukan hendaknya berlandaskan pada kelestarian lingkungan seperti halnya pembangunan berkelanjutan. Menurut Baja (2012) Umar, dkk (2017) pertumbuhan penduduk yang tinggi merupakan salah satu masalah dalam pembangunan berkelanjutan, karena pertumbuhan penduduk yang tidak terkendali akan menurunkan daya dukung lingkungan. Pertumbuhan penduduk akan mendorong penggunaan lahan untuk keperluan tempat tinggal dan fasilitas umum.

$$
\text { Pemanfaatan lahan untuk }
$$

permukiman mempunyai kriteria-kriteria tertentu dilihat dari beberapa aspek yang dapat yang mempengaruhi kawasan permukiman seperti harus berada di kawasan budiaya, tidak berada pada sempadan dan tidak berada pada daerah rawan bencana.

\section{Menurut PERMEN PU}

No.41/PRT/M/2007, Kriteria karakteristik dan kesesuaian lahan permukiman adalah:

1. Topografi datar sampai bergelombang (kelerengan lahan 0-25\%)

2. Tersedia sumber air, baik air tanah, maupun air yang diolah oleh penyelenggara dengan jumlah yang cukup. Untuk PDAM suplai air antara 60 liter/org/hari-100 liter/org/hari.

3. Tidak berada pada daerah rawan bencana (longsor, banjir, erosi, abrasi)

4. Drainase baik sampai sedang

5. Tidak berada pada wilayah sempadan sungai/pantai/waduk/danau/mata air/ saluran pengairan/rel kereta api, dan daerah aman penerbangan

6. Tidak berada pada kawasan lindung

7. Tidak terletak pada kawasan budidaya pertanian/penyangga

8. Menghindari sawah irigasi teknis.

Peningkatan jumlah penduduk maka akan semakin mendorong pemanfaatan lahan untuk dijadikan tempat tinggal pada suatu wilayah, tak terkecuali di Kecamatan Katobu dan Kecamatan Duruka.

Menurut data sensus tahun 2010 jumlah penduduk Kecamatan Katobu adalah 28.360 jiwa dengan kepadatan penduduk mencapai $2.202 \mathrm{jiwa} / \mathrm{Km}^{2}$. Jumlah penduduk Kecamatan Duruka tahun 2010 mencapai 11.207 jiwa dengan kepadatan penduduk mencapai 973 jiwa/ $/ \mathrm{Km}^{2}$.

Menurut data BPS tahun 2018, jumlah penduduk di Kecamatan Katobu mencapai 31.544 jiwa dan Kecamatan Duruka mencapai 12.412 jiwa. Kepadatan penduduk di Kecamatan Katobu 2.449 jiwa/ $\mathrm{Km}^{2}$ dan Kecamatan Duruka mencapai $1.061 \mathrm{jiwa} / \mathrm{Km}^{2}$. 
Menurut data BPS tahun 2011 dan tahun 2018, jika dibandingkan maka terjadi peningkatan jumlah penduduk dan kepadatan penduduk di kecamatan tersebut .Dua kecamatan tersebut merupakan kecamatan yang memiliki laju pertumbuhan penduduk yang tinggi di Kabupaten Muna dengan persentase masingmasing mencapai $1,81 \%$ dan $1,8 \%$ untuk setiap tahunnya.

Pesatnya pertumbuhan penduduk di Kecamatan Katobu dan Kecamatan Duruka tersebut tentu berdampak pada penambahan luas penggunaan lahan permukiman. Berdasarkan hasil wawancara dengan pihak Dinas Perumahan Dan Kawasan Permukiman Kabupaten Muna, telah terdapat permukiman di area hutan yang dujadikan sebagai area perlindungan mata air, sementara menurut peraturan yang berlaku hendaknya pengembangan kawasan permukiman harus menghindari area perlindungn setempat tersebut agar tidak terjadi kerusakan lingkungan yang berkepanjangan yang berdampak pada kelestarian area sekitar mata air.

Pesat pertumbuhan penduduk pada Kecamatan Katobu dan Kecamatan Duruka tidak menutup kemungkinan akan menyebabkan perluasan penggunaan lahan permukiman. Perluasan lahan permukiman yang tidak memperhatikan kesesuain lahan permukiman akan berdampak pada bangunan yang digunakan sebagai tempat tinggal itu sendiri. Oleh karena itu penting adanya informasi terkait kesesuaian lahan permukiman di Kecamatan Katobu dan Kecamatan Duruka agar perluasan permukiman nantinya menghindari lahan yang tidak sesuai, karena pada dasarnya tidak semua lahan cocok untuk permukiman.

\section{METODE PENELITIAN}

Jenis Penelitian

Jenis penelitian ini adalah penelitian desktiptif kualitatif, yang akan memeberikan gambaran mengenai objek yang diteliti yaitu kesesuaian penggunaan lahan permukiman di Kecamatan Katobu dan Kecamatan Duruka.

\section{Waktu dan Tempat Penelitian}

Penelitian ini dilaksanakan pada bulan Januari-Februari 2019 di Kecamatan Katobu dan Kecamatan Duruka Kabupaten Muna.

\section{Sumber Data}

Dalam penelitian ini, peneliti menggunakan data primer dan data sekunder.

1. Data primer berupa hasil wawancara, observasi, dan dokumentasi oleh peneliti selama dilokasi penelitian.

2. Data sekunder berupa data peta-peta parameter yang diperoleh dari instansiinstansi terkait.

\section{Teknik Pengumpulan Data}

Data yang diperoleh peneliti, dikumpulkan melalui dokumentasi, wawancara, dan observasi. Dokumentasi yang dilakukan dalam penelitian ini adalah mengambil dokumen berupa peta-peta dari beberapa instansi, pengambilan gambar pada saat observasi, dan laporan-laporan pendukung lainnya. Wawancara dilakukan kepada Dinas Perumahan dan Kawasan Permukiman Kabupaten Muna untuk mendapatkan data tambahan. Observasi dilakukan dengan meninjau ketepatan hasil pengolahan data berupa peta dengan keadaan sebenarnya dilapangan.

\section{Teknik Analisis Data}

Penelitian ini dilalukan untuk mendapoatkan kesesuaian lahan permukiman dilihat dari aspek fisik lahan, dengan menggunakan parameter kemiringan lereng, jenis tanah, curah hujan, area perlindungan mata air, rawan bencana, sempadan sungai, dan sempadan pantai, yang akan dianalisis dengan menggunakan beberapa teknik, yaitu:

1. Scoring, Overlay, dan Buffer (Analisis spasial).

Scoring dilakukan dengan menggunakan pedoman PERMEN PU No.41/PRT/M/2007 untuk penentuan fungsi kawasan dengan parameter kemiringan lereng, jenis tanah, dan curah hujan, dengan skor adalah sebagai berikut. 
Tabel 1. Klasifikasi dan Skor Faktor Kemiringan Lereng

\begin{tabular}{ccccc}
\hline No & Kelas Lereng & Lereng $(\boldsymbol{\%})$ & Deskripsi & Skor \\
\hline 1 & I & $0-8$ & Datar & 20 \\
2 & II & $8-15$ & Landai & 40 \\
3 & III & $15-25$ & Agak Curam & 60 \\
4 & IV & $25-45$ & Curam & 80 \\
5 & V & $>45$ & Sangat Curam & 100 \\
\hline
\end{tabular}

Sumber: Peraturan Menteri Pekerjaan Umum Nomor 41 Tahun 2007

Tabel 2. Klasifikasi dan Skor Faktor Jenis Tanah

\begin{tabular}{|c|c|c|c|c|}
\hline No & $\begin{array}{l}\text { Kelas } \\
\text { Tanah }\end{array}$ & Jenis Tanah & $\begin{array}{c}\text { Deskripsi } \\
\text { Terhadap Erosi }\end{array}$ & Skor \\
\hline 1 & I & $\begin{array}{l}\text { Aluvial, Tanah Glei, Planosol, Hidromorf Kelabu, } \\
\text { Laterit Air Tanah }\end{array}$ & Tidak Peka & 15 \\
\hline 2 & II & Latosol & Kurang Peka & 30 \\
\hline 3 & III & $\begin{array}{l}\text { Brown Forest Soil, Kambisol, Non Calcic Brown, } \\
\text { Mediteran. }\end{array}$ & Agak peka & 45 \\
\hline 4 & IV & Andosol, Laterit, Grumusol, Podsol, Podsolic & Peka & 60 \\
\hline 5 & $\mathrm{~V}$ & Regosol, Litosol, Arganosol, Renzina. & Sangat Peka & 75 \\
\hline
\end{tabular}

Sumber: Peraturan Menteri Pekerjaan Umum Nomor 41 Tahun 2007

Tabel 3. Klasifikasi dan Skor Faktor Curah Hujan

\begin{tabular}{ccccc}
\hline No & Kelas & Interval (mm/thn) & Deskripsi & Skor \\
\hline 1 & I & $0-1500$ & Sangat Rendah & 10 \\
2 & II & $1500-2000$ & Rendah & 20 \\
3 & III & $2000-2500$ & Sedang & 30 \\
4 & IV & $2500-3000$ & Tinggi & 40 \\
5 & V & $>3000$ & Sangat Tinggi & 50 \\
\hline
\end{tabular}

Sumber: Peraturan Menteri Pekerjaan Umum Nomor 41 Tahun 2007

Data tersebut akan dianalasis Tehnik overlay atau tumpang susun dilakukan menggunakan formula pada aplikasi sistem dengan beberapa parameter hasilnya akan informasi geografis menggunakan teknik berupa peta arahan fungsi kawasan. Berikut overlay dan penambahan masing-masing skor. adalah tabel kriteria fungsi kawasan.

Tabel 4. Kriteria dan Tata Cara Penetapan Kawasan Lindung dan Budidaya.

\begin{tabular}{clc}
\hline No & \multicolumn{1}{c}{ Fungsi Kawasan } & Total nilai skor \\
\hline 1 & Kawasan Lindung & $\geq 175$ \\
2 & Kawasan Penyangga & $125-174$ \\
3 & Kawasan Budidaya tanaman tahunan & $<125$ \\
4 & Kawasan budidaya tanaman semusim dan permukiman & $<125$ dan lereng $<8 \%$ \\
\hline
\end{tabular}

Sumber: Peraturan Menteri Pekerjaan Umum Nomor 41 Tahun 2007

Setelah melakukan analisis fungsi selanjutanya adalah melakukan analisis kawasan, maka akan dilakukan analisis buffer kesesusian lahan permukiman pada fungsi sungai $10 \mathrm{~m}$ untuk menetukan area sempadan kawasan budidaya (skor <125) dengan mengsungai, dan buffer garis pantai $100 \mathrm{~m}$ untuk overlay peta kemiringan lereng, area menentukan area sempadan pantai. tahap perlindungan mata air, daerah rawan bencana, 
area sempadan pantai, area sempadan sungai,setelah memperoleh kesesuaian lahan permukiman, maka akan di-overlay dengan peta penggunaan lahan permukiman untuk menentukan kesesuaian penggunaan lahan permukiman.

\section{Teknik Editing}

Dilakukan dengan cara menyalin ulang hasil wawancara dengan informan dan observasi yang berkaitan dengan kesesuaian penggunaan lahan permukiman, serta memilah data atau informasi.

\section{Statistik Deskriptif}

Statistik deskriptif atau persentase pada penelitian ini digunakan untuk mengetahui persentase tiap kategori kesesuaian lahan permukiman dari seluruh luas daerah penelitian.

\section{Validitas data}

Validitas data dilakukan melalui observasi. Metode sampling yang digunakan dalam melakukan observasi lapangan yaitu purposive sampling. Validasi ini dilakukan di 14 titik dilokasi penelitian.

\section{HASIL DAN PEMBAHASAN \\ Deskripsi Hasil Penelitian \\ Paremeter Kesesusian Lahan Permukiman}

\section{Kemiringan lereng}

Berdasarkan peta kemiringan lereng, Kecamatan Katobu dan Kecamatan Duruks memiliki 2 kelas kemiringsn lereng. Kecamatan Katobu kelas lereng 0-8\% seluas 1385,75 ha dan kelas $8-15 \%$ dengan luas 87,73 ha. Kecamatan Duruka memiliki kelas lereng 0-8\% seluas 1131,73 ha dan kelas lereng $8-15 \%$ seluas 75,66 ha. Klasifikasi kemiringan lereng di Kecamatan Katobu dan Kecamantan Duruka dapat dilihat pada tabel berikut.

Tabel 5. Klasifikasi Kemiringan Lereng di Kec. Katobu dan Kec. Duruka

\begin{tabular}{cccccc}
\hline No & Kecamatan & Kelas Lereng & Skor & Luas (ha) & Persentase \\
\hline 1 & Katobu & $0-8 \%$ (Datar) & 20 & 1385,75 & $51,69 \%$ \\
& & $8-15 \%$ (Landai) & 40 & 87,73 & $3,27 \%$ \\
2 & Duruka & $0-8$ (Datar) & 20 & 1131,73 & $42,22 \%$ \\
& & 8-15\% (Landai) & 40 & 75,66 & $2,82 \%$ \\
\hline \multicolumn{7}{c}{ Jumlah } & & $\mathbf{2 6 8 0 , 8 7}$ & $\mathbf{1 0 0 \%}$ \\
\hline
\end{tabular}

Sumber: Data Olahan ArcGIS, 2019

\section{Jenis Tanah}

Di Kecamatan Katobu dan

litosol dengan luas 557,12 ha dan tanah kambisol seluas 842,81 ha. Kecamatan Duruka memiliki jenis tanah litosol dengan Kecamatan Duruka terdapat 2 jenis tanah, luas 250,07 ha, dan tanah kambisol dengan yaitu jenis tanah litosol dan kambisol. Kecamatan Katobu memiliki jenis tanah luas mencapai 892,94 ha.

Tabel 6. Klasifikasi jenis tanah di Kec. Katobu dan Kec. Duruka

\begin{tabular}{cccccc}
\hline No & Kecamatan & Jenis Tanah & Skor & Luas (ha) & Persentase \\
\hline 1 & Katobu & Kambisol & 45 & 842,81 & $32,81 \%$ \\
& & Litosol & 75 & 579,35 & $22,55 \%$ \\
2 & \multirow{2}{*}{ Duruka } & Kambisol & 45 & 896,11 & $34,88 \%$ \\
& & Litosol & 75 & 250,63 & $9,76 \%$ \\
\cline { 3 - 6 } & & Jumlah & $\mathbf{2 5 6 8 . 9 0}$ & $\mathbf{1 0 0 \%}$ \\
\hline
\end{tabular}

Sumber: Sumber: Data Olahan ArcGIS, 2019

\section{Curah Hujan}

Kecamatan Katobu dan Kecamatan Duruka memiliki intensitas curah hujan yang merata, dengan curah hujan harian $3.61 \mathrm{~mm} /$ hari dan curah hujan tahunan mencapai 1316,63 mm/tahun . 
Tabel 7. Klasifikasi curah hujan di Kec. Katobu dan Kec. Duruka

\begin{tabular}{cccccc}
\hline No & $\begin{array}{c}\text { Curah Hujan } \\
\text { Harian }(\mathbf{m m})\end{array}$ & $\begin{array}{c}\text { Curah Hujan } \\
\text { Tahunan(mm) }\end{array}$ & Skor & Luas & Persentase \\
\hline \multirow{2}{*}{1} & 3,61 & 1316,63 & 10 & 2680,87 & $100 \%$ \\
\cline { 2 - 5 } & Jumlah & & $\mathbf{2 6 8 0 , 8 7}$ & $\mathbf{1 0 0 \%}$ \\
\hline
\end{tabular}

Sumber: Data Olahan ArGIS, 2019

\section{Area Perlindungan Mata Air}

Area perlindungan mata air di Kecamatan Katobu dan Kecamatan dijadikan sebagai kawasan hutan lindung untuk menjaga kelestarian area sekitar. Area perlindungan mata air di Kecamatan Katobu seluas 812,75 ha, sedangkan pada Kecamatan Duruka seluas 165,68 ha.

Tabel 8. Area Perlindungan Mata Air di Kec. Katobu dan Kec. Duruka

\begin{tabular}{ccccc}
\hline No & Kecamatan & Area Perlindunga Mata Air & $\begin{array}{c}\text { Luas } \\
\text { (ha) }\end{array}$ & Persentase \\
\hline \multirow{2}{*}{1} & \multirow{2}{*}{ Katobu } & Area perlindungan mata air & 820,2 & $30,59 \%$ \\
& & APL & 653,28 & $24,37 \%$ \\
2 & \multirow{2}{*}{ Duruka } & Area perlindungan mata air & 165,68 & $6.18 \%$ \\
& & APL & 1041,71 & 38,86 \\
\hline & Jumlah & & $\mathbf{2 6 8 0 , 8 7}$ & $\mathbf{1 0 0 \%}$ \\
\hline
\end{tabular}

Sumber: Data Olahan ArcGIS, 2019

\section{Daerah Rawan Bencana}

Berdasarkan peta-peta rawan bencana (rawan bencana banjir, tanah longsor, dan pergerakan tanah), Kecamatan Katobu dan Kecamatan Duruka bukan merupakan daerah yang rawan bencana. Sehingga indikator daerah rawan bencana pada lokasi penelitian tidak diperhitungkan, karena lokasi penelitian bukan merupakan daerah rawan bencana

\section{Area Sempadan Pantai}

Data peta sempadan pantai dilakukan dengan analisis buffer peta garis pantai sepanjang $100 \mathrm{~m}$ kearah darat. Dari hasil analisis tersebut, luas sempadan pantai di Kecamatan katobu dan Kecamatan Duruka adalah 115,14 ha. Luas sempadan pantai di Kecamatan Katobu adalah 40,85 ha, dan Kecamatan Duruka seluas 74,29ha.

Tabel 9. Wilayah sempadan pantai Kec. Katobu dan Kec. Duruka

\begin{tabular}{cccc}
\hline No & Kecamatan & Luas (ha) & Persentase \\
\hline 1 & Katobu & 40,85 & $35,48 \%$ \\
2 & Duruka & 74,29 & $64,52 \%$ \\
\hline & Jumlah & $\mathbf{1 1 5 , 1 4}$ & $\mathbf{1 0 0 \%}$ \\
\hline
\end{tabular}

Sumber: Data Olahan ArcGIS, 2019

\section{Area sempadan sungai}

Data peta sempadan sungai dilakukan dengan analisis buffer peta sungai ke sisi kiri dan kanan sungai sejauh $10 \mathrm{~m}$. Berdasarkan hasil analisis tersebut, luas sempadan sungai di Kecamatan Katobu dan Kecamatan Duruka adalah 6,91 ha. Di Kecamatan Katobu luas sempadan sungai mencapai 4,03 ha sedangkan di Kecamatan Duruka Mencapai 2,88 ha.

Tabel 10. Sempadan sungai di Kec. Katobu dan Kec. Duruka

\begin{tabular}{cccc}
\hline No & Kecamata & Luas (ha) & Persentase \\
\hline 1 & Katobu & 4,03 ha & $58,32 \%$ \\
& Duruka & 2,88 ha & $41,68 \%$ \\
\hline & Jumlah & $\mathbf{6 , 9 1}$ ha & $\mathbf{1 0 0 \%}$ \\
\hline
\end{tabular}

Sumber: Data Olahan ArcGIS, 2019 


\section{Penggunaan Lahan Permukiman}

Peta penggunaan lahan permukiman di peroleh dari Bappeda Kabupatan Muna dan interpretasi citra satelit untuk menghasilkan peta penggunaan kahan permukiman eksisting. Kecamatan Katobu memiliki penggunaan lahan lahan permukiman yang lebih luas dari Kecamatan Duruka. Kecamatan Katobu memiliki penggunaan lahan permukiman seluas 488,15 ha, sedangkan Kecamatan Duruka memiliki penggunaan lahan permukiman seluas 185,82 ha.

\section{Analisis Fungsi Kawasan}

Analisis fungsi kawasan dilakukan untuk menentukan arahan fungsi kawasan di Kecamatan Katobu dan Kecamatan Duruka, sebagai analisis awal untuk mencari kawasan budidaya sebagai arahan kawasan yang diperuntukkan sebagai permukiman.

Berdasarkan hasil skor dan overlay 3 parameter yaitu kemiringan lereng, jenis tanah, dan curah hujan, terdapat karakteristik 4 satuan unit lahan yang berbeda dengan skor yang berbeda pula. Skor terendah lahan adalah 75 , dan skor tertinggi 125. Sehingga fungsi kawasan di Kecamatan Katobu dan Kecamatan Duruka adalah fungsi kawasan budidaya dan penyangga.

Tabel 11. Klasifikasi Arahan Fungsi Kawasan Berdasarkan 3 Paremeter

\begin{tabular}{ccccc}
\hline No & Interval Total Skor & Fungsi Kawasan & Luas (ha) & Persentase \\
\hline 1 & $<125$ & Budidaya & 2672,64 & $99,70 \%$ \\
2 & $125-174$ & Penyangga & 8,23 & $0,30 \%$ \\
\hline \multicolumn{7}{r}{ Jumlah } & & $\mathbf{2 6 8 0 , 8 7}$ & $\mathbf{1 0 0 \%}$ \\
\hline
\end{tabular}

Sumber: Data Olahan ArcGIS, 2019.

\section{Analisis Kesesusian Lahan Permukiman}

Berdasarkan hasil overlay parameter kesesusian lahan permukiman, di peroleh 3 kelas kesesuaian lahan permukiman di
Kecamatan Katobu dan Kecamatan Duruka, yaitu kelas sesuai, sesuai bersyarat, dan tidak sesuai.
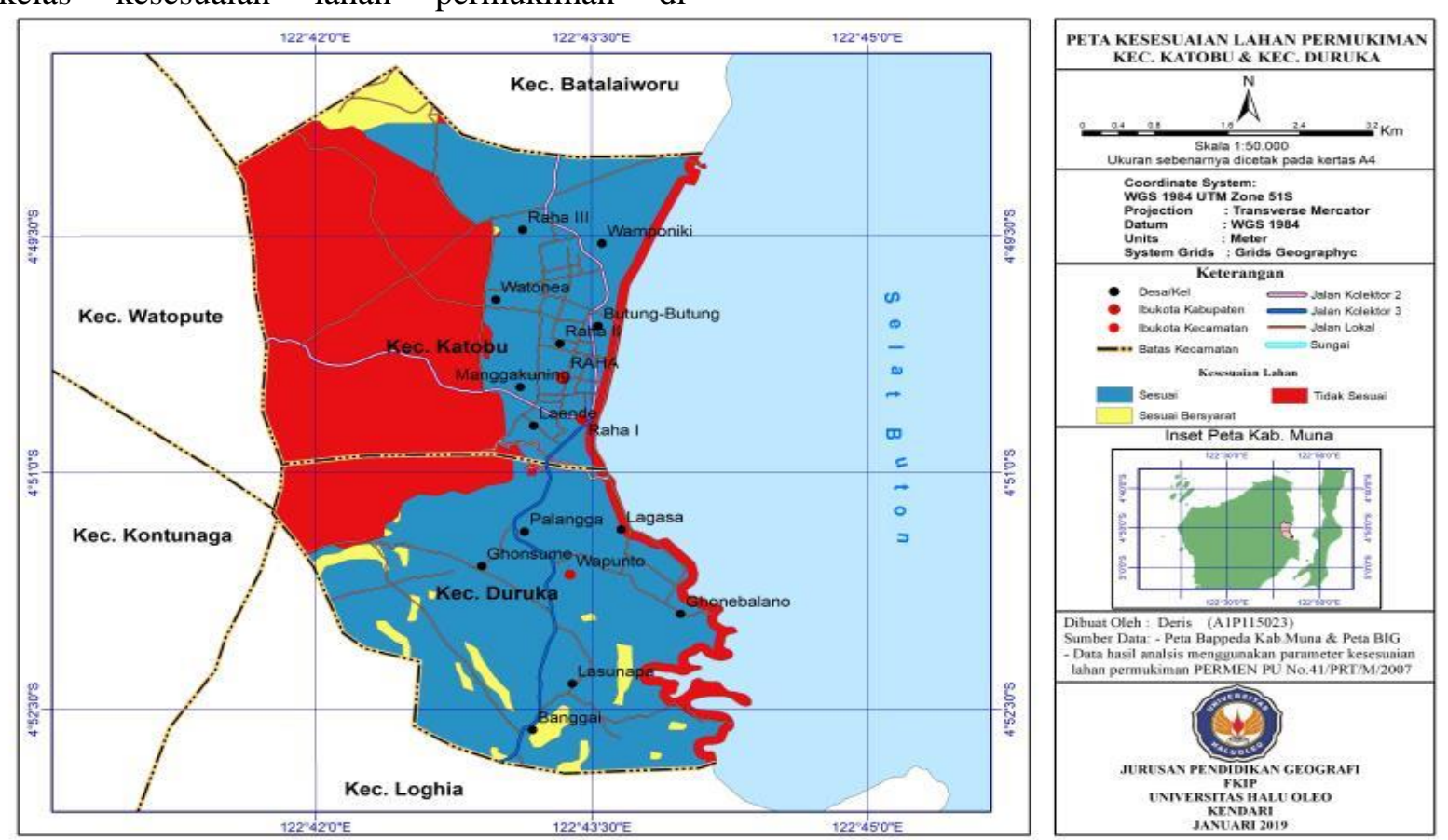

Gambar 1. Peta Kesesusian Lahan Permukiman Kecamatan Katobu dan Kecamatan Duruka (Peta Hasil Analisis Overlay ArcGIS, 2019)

Di kecamatan Katobu lahan sesuai untuk permukiman seluas 551,41 ha, lahan sesuai bersyarat 50,97 ha, dan lahan tidak sesuai seluas 871,1 ha. Di Kecamatan Duruka lahan sesuai untuk permukiman seluas 896,1 ha, lahan sesuai bersyarat seluas 67,81 ha dan lahan tidak sesuai untuk permukiman seluas 243,48 ha. Secara rinci penjabaran dari kelas kesesuaian 
lahan permukiman pada lokasi penelitian disajikan pada tabel berikut.

Tabel 12. Kesesuaian Lahan Permukiman di Kec. Katobu dan Kec. Duruka

\begin{tabular}{cccccc}
\hline No & Kecamatan & Kelas & $\begin{array}{c}\text { Kategori } \\
\text { Kesesuaian }\end{array}$ & $\begin{array}{c}\text { Luas } \\
\text { (ha) }\end{array}$ & Persentase \\
\hline 1 & Katobu & S1 & Sesuai & 551,41 & $37,42 \%$ \\
& & S2 & Sesuai Bersyarat & 50,97 & $3,46 \%$ \\
& & N1 & Tidak Sesuai & 871,1 & $59,12 \%$ \\
& & Jumlah & & $\mathbf{1 4 7 3 , 4 8}$ & $\mathbf{1 0 0 \%}$ \\
2 & Duruka & S1 & Sesuai & 896,1 & $74,22 \%$ \\
& & S2 & Sesuai Bersyarat & 67,81 & $5,62 \%$ \\
& & N1 & Tidak Sesuai & 243,48 & $20,16 \%$ \\
\hline & & Jumlah & & $\mathbf{1 2 0 7 , 3 9}$ & $\mathbf{1 0 0 \%}$ \\
\hline
\end{tabular}

Sumber: Data Olahan ArcGIS 2019

\section{Analisis Kesesuaian Penggunaan Lahan Permukiman}

Analisis ini dilakukan dengan mengoverlay peta hasil analisis kesesuaian lahan permukiman dan peta penggunaan lahan.
Dengan demikian akan diketahui penggunaan lahan permukiman yang berada di lahan sesuai, lahan sesuai bersyarat, dan di lahan tidak sesuai.
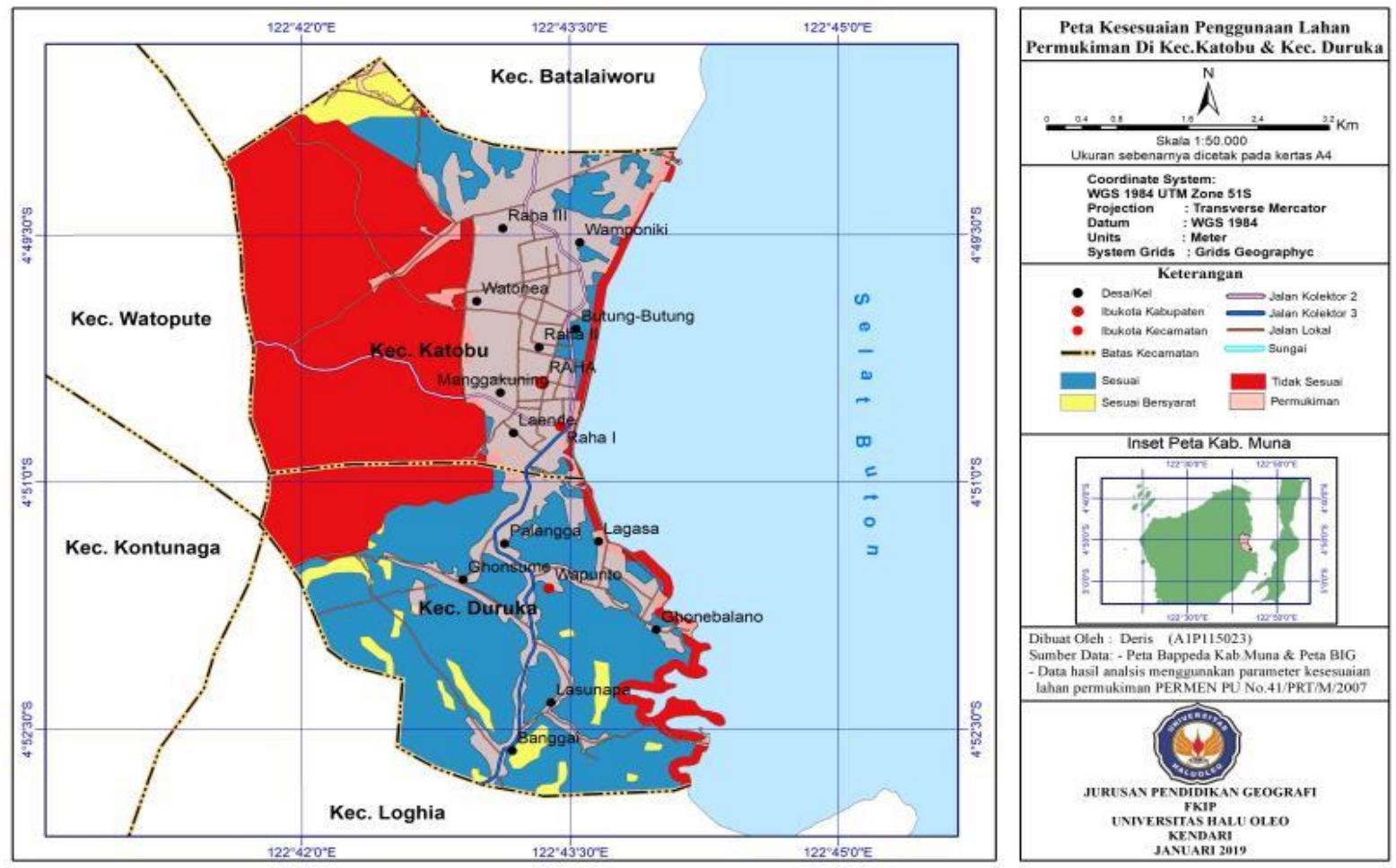

Gambar 2. Peta Kesesuaian Penggunaan Lahan Permukiman Kec. Katobu dan Kec.Duruka (Peta Hasil Analisis Overlay ArcGIS, 2019)

Kecamatan Katobu memiliki penggunaan lahan permukiman di lahan yang sesuai seluas 421,86 ha, di lahan sesuai bersyarat seluas 8,37 ha, dan penggunaan lahan permukiman di lahan tidak sesuai seluas 46,73 ha. Kecamatan
Duruka memiliki penggunaan lahan permukiman di lahan sesuai seluas $172,93 \mathrm{ha}$, dilahan sesuai bersyarat seluas 0,63 ha, dan di lahan tidak sesuai seluas 12,26 ha. 
Tabel 13. Kesesuaian Penggunaan Lahan Permukiman di Kec. Katobu dan Kec. Duruka

\begin{tabular}{|c|c|c|c|c|c|c|c|c|c|}
\hline \multirow[t]{3}{*}{ No } & \multirow{3}{*}{ Kecamatan } & \multicolumn{6}{|c|}{ Penggunaan Lahan Permukiman } & \multicolumn{2}{|c|}{ Jumlah } \\
\hline & & \multicolumn{2}{|c|}{ Sesuai (S1) } & \multicolumn{2}{|c|}{$\begin{array}{c}\text { Sesuai } \\
\text { Bersyarat } \\
\text { (S2) }\end{array}$} & \multicolumn{2}{|c|}{$\begin{array}{c}\text { Tidak Sesuai } \\
\text { (N1) }\end{array}$} & & \\
\hline & & На & $\%$ & На & $\%$ & Ha & $\%$ & Ha & $\%$ \\
\hline 1 & Katobu & 421,86 & 88,45 & 8,37 & 1,75 & 46,73 & 9,80 & 476,96 & 100 \\
\hline 2 & Duruka & 172,93 & 93.06 & 0,63 & 0,34 & 12,26 & 6,60 & 185,82 & 100 \\
\hline
\end{tabular}

Sumber: Data Olahan ArcGIS, 2019.

\section{PEMBAHASAN}

\section{Kesesusian Lahan Permukiman}

Berdasarkan hasil pengolahan data parameter-parameter kesesuaian lahan permukiman melalui SIG, diperoleh 3 kelas kesesuaian lahan permukiman di Kecamatan Katobu dan Kecamatan Duruka, yaitu sesuai (S1), sesuai bersyarat (S2) dan tidak sesusia (N1).

Lahan kelas sesuai (S1), pada kelas ini lahan tidak mempunyai faktor pembatas yang berarti atau nyata terhadap penggunaan secara berkelanjutan, atau faktor pembatas bersifat minor dan tidak akan berpengaruh terhadap produktivitas lahan secara nyata baik untuk permukiman. Pada lokasi penelitian, lahan pada kelas ini merupakan lahan untuk permukiman yang secara fungsi kawasan merupakan kawasan budidaya, kemiringan lereng $0-8 \%$, lahan yang tidak terdapat faktor pembatas seperti fungsi kawasan lindung, fungsi kawasan penyangga, area perlindungan mata air, daerah rawan becana, area sempadan sungai, area sempadan pantai. Kecamatan katobu memiliki lahan sesuai (S1) seluas 551,41 ha, sednagkan kecamatan duruka seluas 896,1 ha.

Lahan kelas sesuai bersyarat (S2) Lahan mempunyai faktor pembatas agak berat, berpengaruh terhadap produktivitas lahan tersebut, memerlukan tambahan masukkan. Pembatas tersebut biasanya dapat diatasi. Lahan pada kelas S2 (sesuai bersyarat) merupakan lahan yang secara fungsi kawasan merupakan fungsi kawasan budidaya, lahan kemiringan lereng $8-15 \%$, Lahan yang tidak terdapat faktor pembatas seperti fungsi kawasan lindung dan penyangga, area perlindungan mata air, daerah rawan becana, area sempadan sungai, dan dan area sempadan pantai. Faktor pembatas pada lahan ini adalah kemiringan lereng $8-15 \%$.

Pada lahan ini sebagaimana menurut PERMEN PU Pd T-03-2005-C tentang cara pemilihan lokasi prioritas perumahan dan permukiman, membutuhkan rekayasa teknis. Sebagaimana pula menurut Bappeda Dalam RP3KP (2018) bahwa lahan pada lereng 8-15\% dapat digunakan untuk kegiatan permukiman dan pertanian, tetapi bila terjadi kesalahan dalam pengelolahannya masih mungkin terjadi erosi. Lahan kelas sesuai bersyarat (S2) di Kecamatan Katobu seluas 50,97 ha, sedangkan pada Kecamatan Duruka seluas 67,81 ha.

Lahan kelas tidak sesuai untuk permukiman (N1) merupakan lahan yang mempunyai faktor pembatas yang sangat berat dan/atau sulit diatasi untuk permukiman. Pada kelas ini satuan lahan tidak dapat dijadikan sebagai lokasi permukiman karena memilik faktor pembatas seperti fungsi kawasan penyangga, area perlindungan mata air, lahan yang berada pada area sempadan sungai, dan lahan yang berada pada area sempadan pantai. Apabila suatu lahan berada pada salah satu faktor pembatas tersebut, maka akan di tetapkan sebagai lahan tidak sesuai untuk permukiman sebagaimana peraturan yang berlaku. Kecamatan Katobu memiliki lahan tidak sesuai (N1) untuk permukiman seluas 871,1 ha, sedangkan Kecamatan Duruka seluas 243,48 ha.

\section{Kesesuaian Penggunaan Lahan Permukiman}

Berdasarkan hasil overlay peta hasil analisis kesesuaian lahan permukiman dengan peta penggunaan lahan permukiman eksisting, maka di peroleh kesesuaian penggunaan lahan permukiman pada masing-masing kelas kesesuaian lahan permukiman.

Penggunaan lahan permukiman di lahan sesuai (S1) pada kecamatan katobu seluas 421,68 ha, sedangkan pada Pada Kecamatan Duruka seluas 172,93 ha.

Penggunaan lahan permukiman di lahan kelas sesuai bersyarat di Kecamatan Katobu 
seluas 8,37 ha, sedangkan di Kecamatan Duruka seluas 0,63 ha. Rekayasa teknis pada lahan sesuai bersyarat untuk permukiman dilokasi penelitian dilakukan dengan cara mengurangi tingkat kerapatan bangunan, pengurangan keterjalanan lereng dalam lingkup kecil. Pengurangan keterjalan lereng dilakukan mengikuti bentuk pondasi bangunan rumah, sehingga tidak merubah bentuk lereng dalam skala besar. Selain itu, bentuk rekayasa teknis lainnya adalah pembangunan pondasi yang kokoh.

Penggunaan lahan permukiman di lahan tidak sesuai (N1) pada Kecamatan Katobu seluas 46,73 ha, sedangka kecamatan Duruka seluas 12,26 ha.

Berdasarkan hasil wawancara dengan pihak Dinas Perumahan Dan Kawasan Permukiman Kab.Muna, telah dilakukan perbaikan dan penyelesiana pada permukiman dilahan tidak sesuai. Perbaikan yang dilakukan tergantung faktor pemabatas lahan tersebut. Pada lahan tidak sesuai dengan faktor pemabatas area perlindungan mata air menjadi permaslahan utama, dengan bentuk penyelesaian tidak dikleuarkannya IMB, dilakukan penimbunana area pantai untuk keperluan perluasan permukiman di Kecamatan Katobu, dan tidak diadakannya jalan dan pembuatan system drainase pada permukiman tersebut. padahal tidak seusia dengan faktor pembatas area sempadan pantai dilakukan dengan perbaikan secara terus menerus karena sering kali mengalami kerusakan. Perbaikan tersebut dilakukan dengan cara pembuatan jalan bypass untuk penahan abrasi, penimbunan area pantai, dan yang terakhir dilakukan adalah pembuatan tanggul penahan abrasi. Perbaikan pada lahan tidak sesuai dengan faktor pembatas area sempadan sungai dilakukan dengan cara pembuatan jalan mengikuti alur sungai agar tidak terdapat permukiman di sepanjang area sempadan sungai.

\section{SIMPULAN DAN SARAN Kesimpulan}

1. Terdapat 3 kategori kelas kesesuaian lahan permukiman di Kecamatan Katobu dan Kecamatan Duruka. Kecamatan Katobu didominasi oleh lahan tidak sesuai untuk permukiman seluas 871,1 ha dengan faktor pembatas fungsi kawasan penyangga, area perlindungan mata air, area sempadan pantai dan area sempadan sungai. Lahan sesuai untuk permukiman di Kecamatan Katobu seluas 551,41ha, dan lahan sesuai bersyarat untuk permukiman seluas 50,97 ha dengan faktor pembatas kemiringan lereng $8-15 \%$. Kecamatan Duruka memiliki kesesuaian lahan permukiman yang didominasi oleh lahan sesuai untuk permukiman seluas 869,1 ha, lahan sesuai bersyarat seluas 67,81 ha dengan faktor pembatas kemiringan lereng 8-15\% dan lahan tidak sesuai untuk permukiman seluas 243,48 ha dengan faktor pembatas fungsi kawasan penyangga, area perlindungan mata air, sempadan pantai, dan sempadan sungai.

2. Kesesuaian penggunaan lahan permukiman menunjukkan, Kecamatan Katobu memiliki penggunaan lahan permukiman di lahan sesuai seluas 421,86 ha, penggunaan lahan permukiman dilahan sesuai bersyarat seluas 8,37 ha, dan penggunaan lahan permukiman dilahan tidak sesuai 46,73 ha. Kecamatan Duruka memiliki penggunaan lahan permukiman pada lahan sesuai 172,93 ha, penggunaan lahan permukiman pada lahan sesuai bersyarat seluas 0,63 ha dan penggunaan lahan permukiman pada lahan tidak sesuai seluas 12,26.

\section{Saran}

1. Dalam memilih lokasi untuk permukiman sebaiknya menghindari lahan yang tidak sesuai dengan peruntukannya, karena penggunaan lahan terutama permukiman pada zona yang tidak layak huni akan berdampak menimbulkan kerusakan lingkungan dan bencana.

2. Sebaiknya perlu adanya pemberian sanksi tegas terhadap masyarakat yang membangun area permukiman di lahan yang tidak sesuai terutama di kawasan lindung terlebih lagi jika tidak memiliki IMB, agar selanjutnya tidak terdapat lagi pembangunan rumah di area permukiman pada kawasan lindung.

3. Sebaiknya pemerintah setempat lebih teliti dalam memberikan izin terutama yang menyangkut masalah perubahan tataguna lahan, seperti dari area hutan lindung diberikan izin melakukan kegiatan perkebunan agar tidak terdapat permukiman pada lahan yang sebelumnya digunakan sebagai area perkebunan tersebut. 


\section{DAFTAR PUSTAKA}

Baja, S. 2012. Perencanaan Tata Guna Lahan Dalam Pengembangan Wilayah. Yogyakarta: ANDI

BAPPEDA. 2019. Laporan Akhir Rencana Pembangunan dan Pengembangan Perumahan dan Kawasan Permukiman (RP3KP) Kabupatan Muna 2018. BAPPEDA Kabupaten Muna

BPS. 2018. Kecamatan Duruka Dalam Angka 2018.

https://munakab.bps.go.id/publication/20 18/09/20 (Diakses 2 November 2018)

BPS. 2018. Kecamatan Katobu Dalam Angka 2018.

https://munakab.bps.go.id/publication.ht $\mathrm{ml}$ (Diakses 02 November 2018)

BPS, 2011. Kabupaten Muna Dalam Angka 2011.

https://munakab.bps.go.id/publication/20 12/01/16//muna-dalam-angka-2011.html. (Diakses 02 November 2018)

Lestari, R. W., Indra K, dan Yode A. 2016. Sistem Informasi Geografis (SIG) Daerah Rawan Banjir Di Kota Bengkulu Menggunakan ArcView. Jurnal Media Infotama 12 (1): 41-48

PERMEN PU No. 41/PRT/M/2007 TENTANG PEDOMAN KRITERIA KAWASAN BUDIDAYA.

Prahasta, Eddy. 2009. Sistem Informasi Geografis. Bandung: Informatika Bandung

Umar, Iswandi., Widiatmaka, Bambang. P, \& Baba. B. 2017. Evaluasi Keseuaian Lahan Untuk Permukiman Dengan Metode Multi Criteria Evaluation Di Kota Padang. Jurnal Pengelolaan Sumber Daya Alam Dan Lingkungan. 7 (2): $148-154$

Pengelola Jurnal Penelitian Pendidikan Geografi

La Ode Amaluddin

Gedung FKIP Lt. 2 Universitas Halu Oleo.

Kampus Bumi Tridharma Anduonohu Kendari93232

Email: amaluddin.75@gmail.com 